\title{
Pembuatan Game Edukasi Mengenai Materi Hafalan Doa Harian Sebagai Media Pembelajaran Berbasis Android
}

\author{
Dinda Septarini $^{a}$ \\ ${ }^{a}$ Politeknik Negeri Media Kreatif, Jakarta
}

INFORMASI ARTIKEL

Sejarah Artikel:

Diterima Redaksi: 2 Mei 2020

Diterbitkan Online: 15 Juli 2020

\section{KATA KUNCI}

game edukasi, SDIT Mentari, menghafal doa-doa harian, media , pembelajaran interaktif

\section{KORESPONDENSI}

Email : septarinidinda@gmail.com

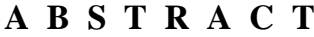

Kemampuan membaca, menulis dan menghafal Al-Qur'an mutlak harus dimiliki oleh semua umat Islam untuk dapat memahami, menghayati, kemudian mengamalkan apa yang terkandung di dalamnya. Salah satunya menghafal doa-doa harian yang terdapat pada Mata Pelajaran Pendidikan Agama Islam. Oleh karena itu anak harus ditekankan untuk belajar membaca, menulis, dan menghafal Al-Qur'an sejak dini, sehingga mereka mampu membaca, menulis dan menghafal Al-Qur'an dengan baik dan benar. salah satu caranya adalah dengan menyekolahkan anak ke lembaga pendidikan berbasis islami seperti SDIT Mentari Ciangsana. Sekolahan ini menerapkan kurikulum 2013 yang terdapat beberapa doa-doa harian, namun doa-doa harian tersebut tidak semuanya tercantum dalam buku paket maupun lembar kerja siswa (LKS). Sekolahan ini juga belum memiliki metode pembelajaran yang interaktif untuk membantu hafalan murid. Game edukasi dapat mendorong siswa untuk belajar aktif dan kreatif, dan tidak merasa bosan saat belajar, serta dapat meningkatkan daya dan minat belajar anak. Game edukasi yang dibuat diberi nama "Menghafal Doa-Doa harian". Hasil keluaran game yang dibuat berupa game berbasis Android dengan materi soal-soal yang ditampilkan secara acak dan beberapa dari buku pelajaran PAI kelas 1 sampai 4, ada juga tambahan doa-doa yang belum tercantum di buku tersebut, yang digunakan SDIT Mentari Ciangsana.

\section{PENDAHULUAN}

Kemampuan membaca, menulis dan menghafal Al-Qur'an mutlak harus dimiliki oleh semua umat Islam untuk dapat memahami, menghayati, kemudian mengamalkan apa yang terkandung di dalamnya. Oleh karena itu anak harus ditekankan untuk belajar membaca, menulis, dan menghafal Al-Qur'an sejak dini, sehingga mereka mampu membaca, menulis dan menghafal AlQur'an dengan baik dan benar.

Doa merupakan salah satu sarana untuk berkomunikasi antara hamba dengan Allah SWT. Dalam keadaan tertentu. ${ }^{[1]}$ Oleh karena itu, doa bukan hanya semata-mata untuk memohon pertolongan Allah SWT dalam memecahkan masalah manusia yang dihadapinya, akan tetapi dalam konteks secara luas sebagai suatu kebutuhan dalam rangkaian ibadah. Demikian pula orang yang berdoa kepada Allah SWT. Setiap kali seseorang mengangkat kedua tangannya ke langit sambil mengatakan,"Wahai Rabb-ku, Wahai Rabb-ku" dan bersungguh-sungguh dalam doanya, maka Allah SWT. Akan memberikan pahala atas doanya tersebut, baik doanya tersebut dikabulkan atau ditunda pengabulannya oleh Allah SWT. Sebagaimana Rasulullah SAW bersabda,

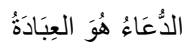

"Doa adalah ibadah." (HR. Tirmidzi no. 2969. Dinilai shahih oleh Syaikh Al-Albani). ${ }^{[2]}$ 
Pendidikan agama sama pentingnya dengan pendidikan pelajaran sekolah untuk anak-anak ditahap sekolah dasar. Para orang tua berpikir anak mereka akan lebih paham jika diajarkan pendidikan agama sedini mungkin pada anak-anak. ${ }^{[3]}$ Mata Pelajaran Pendidikan Agama Islam terdapat doa-doa harian, yang dimana tidak semua anak-anak menerapkannya dikehidupan sehari-hari.

Saat ini masih banyak instansi pendidikan yang menyampaikan informasi tentang materi pembelajaran yang belum di sampaikan secara visual melainkan secara non visual, salah satu instansi pendidikan yaitu SDIT Mentari menerapkan sistem pembelajaran kurikulum 2013 (K13). Dalam Kompetensi Inti (KI) dan Kompetensi Dasar (KD) Pendidikan Agama Islam Dan Budi Pekerti SD/MI pada Lampiran Permendikbud RI No. 024 Tahun 2016, murid diajarkan untuk melafalkan, menghafalkan, dan mengimplementasikan pemahaman tentang suratsurat pendek. Sekolahan ini masih menggunakan media pembelajaran buku paket dan LKS (Lembar Kerja Siswa). Untuk materi tentang doa-doa harian di buku paket maupun LKS (Lembar Kerja Siswa) masih kurang lengkap, maka dari itu dibutuhkan sebuah media pembelajaran interaktif bagi murid untuk menghafalkan doa-doa harian yaitu game edukasi.

Dengan penggunaan metode yang kurang tepat dan kurang lengkap, bisa menimbulkan siswa menjadi pasif, dan bahkan kurang memahami dan menerima materi yang disampaikan sehingga nilai yang di dapat masih banyak yang tidak mencapai KKM, termasuk materi hafalan doa-doa harian. Di SDIT Mentari terdapat peserta didik yang mudah dalam hafalan, yang lambat dalam hafalan, dan ada yang sangat sulit dalam menghafal. Hasil data menyatakan bahwa peserta didik mengalami kesusahan dalam menghafal, jika peserta didik mendapatkan nilai dibawah KKM, guru Pendidikan Agama Islam (PAI) di SDIT Mentari berusaha dengan maksimal melakukan remedial kepada peserta didik sampai mendapatkan nilai diatas KKM. Berikut data jumlah peserta didik dan hasil jumlah nilai peserta didik kelas 4 Mina hafalan doa harian semester 1 dan semester 2 yang dapat dilihat dibawah ini :

Tabel 1. 1 Nilai Rata-Rata Kelas 4

\begin{tabular}{|l|c|c|l|}
\hline $\begin{array}{l}\text { Jumlah } \\
\text { Siswa }\end{array}$ & Semester & $\begin{array}{c}\text { Jumlah Nilai } \\
\text { Kelas }\end{array}$ & $\begin{array}{l}\text { Nilai Rata- } \\
\text { Rata Kelas }\end{array}$ \\
\hline
\end{tabular}

\begin{tabular}{|l|c|c|c|}
\hline \multirow{2}{*}{22 Orang } & I & 1.539 & 70 \\
\cline { 2 - 4 } & II & 1.600 & 73 \\
\hline
\end{tabular}

Sumber : SDIT Mentari

$\begin{array}{ll}\text { KKM Semester I } & =75 \\ \text { KKM Semester II } & =77\end{array}$

Nilai rata-rata kelas : Jumlah silai

Kesimpulan dari data diatas nilai rata-rata kelas 4 Mina semester $\mathrm{I}=70$ dan semester II $=73$. Nilai rata-rata kelas masih di bawah nilai KKM, serta dari hasil wawancara dengan guru PAI, dilihat dari nilai peserta didik yang belum mencapai KKM, guru PAI sangat setuju dengan adanya metode pembelajaran baru dalam menghafal doa harian.

Saat ini SDIT Mentari salah satu sekolah yang kini belajar dirumah dan menggunakan sistem pembelajaran daring, yang dimana kegiatan di sekolah pun di hentikan selama kondisi tersebut masih memprihatinkan yang di sebabkan penyebaran virus yaitu corona atau dikenal dengan istilah Covid-19 (Corona Virus Diseases-19). Sehingga menghambat proses belajar termasuk dalam materi hafalan doa-doa harian. Di dalam keadaan sekarang ini sangat dibutuhkan metode pembelajaran baru yang membuat anak-anak lebih aktif dalam menghafal doa-doa harian. Salah satunya Game edukasi dapat digunakan sebagai salah satu media pendidikan yang bisa digunakan sebagai media pembelajaran. Game jenis ini biasa digunakan untuk mengajak penggunanya belajar sambil bermain. Melalui proses belajar ini maka penggunanya dapat memperoleh ilmu pengetahuan, sehingga game edukasi merupakan inovasi baru yang digunakan dalam dunia pendidikan. Selain dikarenakan game jenis ini memadukan antara sisi belajar dan bermain, game jenis ini juga dapat digunakan untuk menarik perhatian anak-anak untuk belajar.

Permasalahan yang ditemukan pada penelitian ini bersangkutan dengan penelitian sebelumnya dengan judul Game Edukasi Menghafal Doa-Doa Harian Sebagai Media Belajar Untuk Anak Usia Dini Berbasis Android karya Topan Ramadhan SAN dan Fatah Yasin Al Irsyadi yang menciptakan aplikasi game edukasi berbasis android untuk anak PAUD Aisyiyah karna belum adanya pemanfaatan media belajar yang interaktif dalam proses 
pembelajaran doa harian, Desain Aplikasi Pembelajaran Doa-Doa Harian Berbasis Game Edukasi karya Hermansyah, Leo Fajar Gustomi, Nurhayati yang menciptakan media pembelajaran berbasis game edukasi di TK Islam MTA untuk meningkatkan konsentrasi anak dalam melaksanakan proses belajar dan mempermudah guru dalam memberi pelajaran kepada anak dengan nyaman dan menyenangkan, Rancang Bangun Aplikasi Game Edukasi Hafalan Doa Agama Islam karya Muzliah Rizka Hamadi, Arie S. M. Lumenta, Muhamad D. Putro yang menciptakan aplikasi game edukasi hafalan doa agama islam untuk membantu anak-anak dan guru-guru dalam menghafalkan doa harian. Mempelajari doa harian merupakan salah satu kegiatan pembelajaran. Seperti telah diketahui ada berbagai macam buku pembelajaran mengenai doa harian, namun isi dari buku tersebut tidak bersifat interaktif. Untuk membangkitkan motivasi minat belajar peserta didik terhadap doa harian perlu dikembangkan suatu metode pembelajaran yang interaktif dimanapun dan kapanpun mereka berada.

Berdasarkan permasalahan diatas, peneliti bermaksud untuk menciptakan sebuah game edukasi yang dapat digunakan sebagai media belajar oleh peserta didik SDIT Mentari, khususnya dalam kompentensi hafalan doa harian.

\section{TINJAUAN PUSTAKA}

\subsection{Game}

\subsubsection{Sejarah Game}

Teori permainan (Game) mula-mula dikemukakan oleh seorang ahli matematika Perancis Emile Borel (1921). Kemudian dikembangkan oleh John V,N dan Oscar Mogenstern lebih lanjut sebagai alat untuk merumuskan perilaku ekonomi bersaing yang berisi "Permainan terdiri atas sekumpulan peraturan yang membangun situasi bersaing dari dua sampai beberapa orang atau kelompok dengan memilih strategi yang dibangun untuk memaksimalkan kemenangan sendiri atau pun untuk meminimalkan kemenangan lawan. Peraturan-peraturan menentukan kemungkinan tindakan untuk setiap pemain, sejumlah keterangan diterima setiap pemain sebagai kemajuan bermain, dan sejumlah kemenangan atau kekalahan dalam berbagai situasi". ${ }^{[4]}$

\subsubsection{Pengertian Game}

Game merupakan istilah yang berarti permainan, didalam dunia teknologi informasi istilah ini digunakan untuk sarana hiburan yang menggunakan perangkat elektronik. "Game adalah suatu sistem atau program dimana satu atau lebih pemain mengambil keputusan melalui kendali pada objek di dalam game untuk tujuan tertentu" (Jasson, 2009). ${ }^{[4]}$

\subsection{Game Edukasi}

game edukasi merupakan salah satu jenis game yang tidak hanya bersifat menghibur tetapi didalamnya mengandung pengetahuan yang disampaikan kepada penggunanya. Game edukasi dapat digunakan sebagai salah satu media pendidikan yang bisa digunakan sebagai media pembelajaran. Game jenis ini biasa digunakan untuk mengajak penggunanya belajar sambil bermain. Melalui proses belajar ini maka penggunanya dapat memperoleh ilmu pengetahuan, sehingga game edukasi merupakan terobosan baru yang digunakan dalam dunia pendidikan. Selain dikarenakan game jenis ini memadukan antara sisi belajar dan bermain, game jenis ini juga dapat digunakan untuk menarik perhatian anak-anak untuk belajar. ${ }^{[5]}$

\subsection{Pengertian Android}

Android adalah sebuah sistem operasi untuk perangkat mobile berbasis linux yang mencakup sistem operasi, middleware dan aplikasi. Android menyediakan platform terbuka bagi para pengembang untuk menciptakan aplikasi mereka. Awalnya, Google Inc. Membeli Android Inc. Yang merupakan pendatang baruu yng membuat peranti lunak untuk ponsel/smartphone. Kemudian untuk mengembangkan Android, dibentuklah Open Handset Alliance, konsorsium dari 34 perusahaan peranti keras, peranti lunak, dan telekomunikasi, termasuk Google, HTC, Intel, Motorola, Qualcomm, T-Mobile, dan Nvidia, (Kurniawan, 2011). ${ }^{[6]}$

Menurut Akhmad Dharma Kasman (2016:2), "Android adalah sebuah sistem operasi telepon seluler dan komputer tablet layer sentuh (touchscreen) yang berbasis linux." Namun seiring perkembangannya, android berubah menjadi platform yang begitu cepat dalam melakukan inovasi. Hal ini tidak lepas dari pengembang utama dibelakangnya yaitu Google. Google-lah yang mengakusisi android, kemudian membuatkan sebuah platform. Platform android terdiri dari sistem operasi berbasis linux, sebuah GUI (Graphic User Interface), sebuah web browser dan aplikasi end-user yang dapat di download dan juga para pengembang bisa dengan leluasa berkarya serta 
menciptakan aplikasi yang terbaik dan terbuka untuk digunakan oleh berbagai macam perangkat. ${ }^{[7]}$

Pada tanggal 09 Desember 2008, ada 14 anggota baru yang akan bergabung di dalam proyek Android, termasuk Packet Video, ARM Holdings, Atheros Communication, Asustek Computer INC, Garmin Ltd, Softbank, Sony Ericsson, Toshiba Corp, dan VodaFone Group Plc (Hermawan, 2010). ${ }^{[8]}$

\subsection{Doa-Doa Harian}

Doa artinya permohonan atau harapan, permintaan, pujian kepada tuhan. Sedangkan berdo'a yaitu mengucapkan atau memanjatkan doa kepada Tuhan. (KBBI, 2003). Membiasakan diri melatih anak mengucapkan doa/lapadz/-lapadz bacaan sholat seperti yang dilakukan oleh Hambali kepada anaknya merupakan Langkah awal untuk menanamkan rasa cinta terhadap Allah SWT. Bagi anak, juga merupakan salah satu cara untuk membentuk tauhid bagi anak usia dini. Menanamkan tauhid kepada anak sebenarnya bisa dimulai sejak usia 0-2 tahun. Untuk menanamkan tauhid pada masa ini, Rasulullah telah memberikan contoh mengumandangkan adzan ke telinga cucunya Hasan yang baru lahir (Imam Musbikin, 2003). ${ }^{[9]}$

Berdasarkan Kompetensi Inti (KI) dan Kompetensi Dasar (KD) Pendidikan Agama Islam Dan Budi Pekerti SD/MI Kurikulum 2013, setiap satu semester terdapat bacaan doa-do harian, seperti

a) Doa sebelum belajar.

b) Doa sesudah belajar.

c) Doa kedua orang tua.

d) Doa masuk kamar mandi.

Penulis akan menambahkan beberapa doa harian yang terdapat di game tersebut, berikut kumpulan doa-doa harian :

a) Doa keluar kamar mandi.

b) Doa sebelum makan.

c) Doa sesudah makan.

d) Doa sebelum tidur.

e) Doa bangun tidur

f) Doa masuk rumah

g) Doa keluar rumah

\subsection{Flowchart}

Flowchart adalah adalah suatu bagan dengan simbol-simbol tertentu yang menggambarkan urutan proses secara mendetail dan hubungan antara suatu proses (instruksi) dengan proses lainnya dalam suatu program. Dalam perancangan flowchart sebenarnya tidak ada rumus atau patokan yang bersifat mutlak (pasti). Hal ini didasari oleh flowchart (bagan alir) adalah sebuah gambaran dari hasil pemikiran dalam menganalisa suatu permasalahan dalam komputer. Karena setiap analisa akan menghasilkan hasil yang bervariasi antara satu dan lainnya. Kendati begitu secara garis besar setiap perancangan flowchart selalu terdiri dari tiga bagian, yaitu input, proses dan output. ${ }^{[10]}$
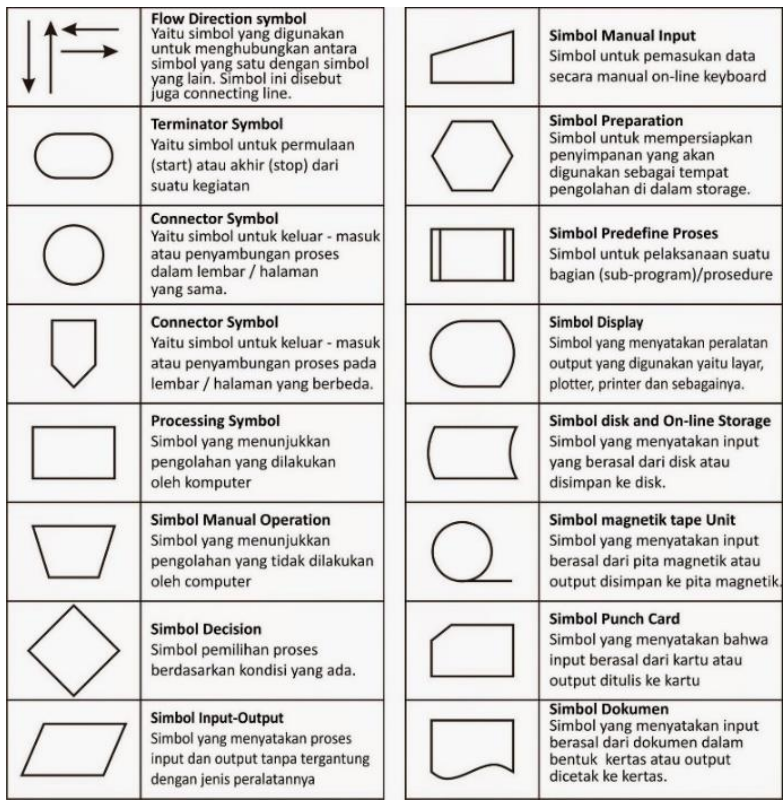

Gambar 2. 1 Simbol Flowchart

Sumber : informatikalogi, 2017

\section{KONSEP PERANCANGAN}

\subsection{Profil SDIT Mentari}

SDIT Mentari adalah Sekolah Dasar Islam Terpadu yang berada di Komp.TNI AL, Jl. Teluk Tomini VIII, Blok DD 1 No. 1 A, Desa Ciangsana, Kecamatan Gunungputri, Bogor. Sekolah ini dirikan pada tahun 2004, yang berakreditasi A.

\subsection{Metode Pembelajaran Yang Sedang Berjalan}

Metode pembelajaran yang sedang diterapkan di SDIT Mentari lebih sering menggunakan metode konvensional yaitu pengajaran menggunakan media buku paket, Lembar Kerja Siswa (LKS) dan pengajaran secara langsung dari guru, terkadang menggunakan media proyektor sebagai proses daya tarik bagi peserta didik dalam mata pelajaran Pendidikan Agama Islam (PAI).

\subsection{Media Pembelajaran Yang Akan Dibuat}




\subsubsection{Deskripsi Karya}

Ide pembuatan game menghafal doa-doa harian ini penulis dapatkan dari hasil diskusi dengan rekan teman-teman yang bersangkutan, untuk hasil pencarian data penulis dapat dari hasil wawancara dengan guru PAI SDIT Mentari. Setelah itu penulis mulai merancang konsep pembuatan game edukasi untuk peserta didik SDIT Mentari dalam menghafal doa-doa harian. Konsep yang dikembangkan dalam pembuatan game ini adalah dengan meciptakan game edukasi berbasis Android yang mudah dipahami saat dimainkan oleh anak-anak. Misi game ini adalah mencocokan doa, menebak doa, dan melengkapi doa menjadi satu ayat yang berurut dan utuh. Dengan begitu murid akan mengingat kembali doa-doa harian yang dipelajari dan melatih daya ingat mereka. Materi doa-doa harian yang ditampilkan dalam game ini bersumber dari buku mata pelajaran PAI kelas 1-4 yang digunakan di SDIT Mentari, serta tambahan doa dari referensi buku doa-doa. Game edukasi ini diberi nama "Menghafal Doa-Doa Harian". Game ini terdiri dari 3 level. level 1 mencocokan doa, level 2 menebak doa, level 3 melengkapi doa, setiap level terdiri dari 10 soal.

\subsubsection{Proses}

Adapun proses pembuatan game edukasi yaitu melalui 3 tahap, yaitu tahap pra produksi yang dilaksanakan sebelum pembuatan karya, tahap produksi yaitu tahap mulai pembuatan karya, dan tahap pasca produksi yaitu pengujian setelah karya selesai dibuat.

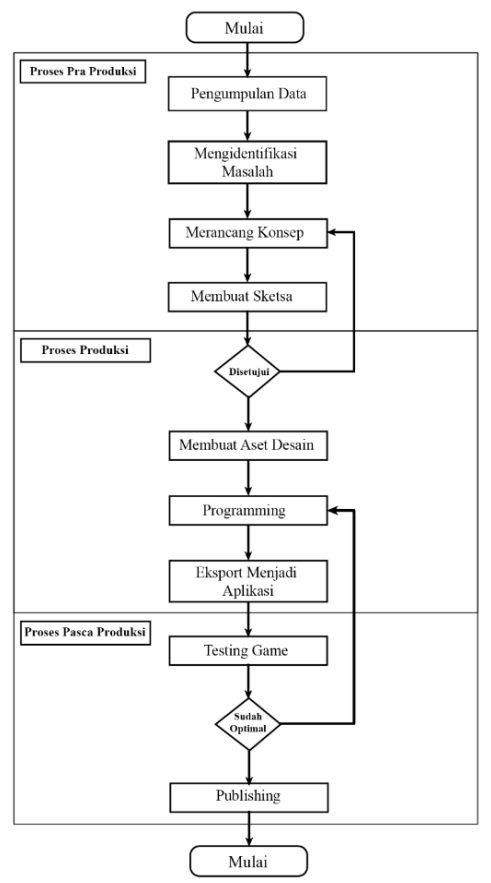

Gambar 3. 1 Alur Proses

Sumber : penulis

\subsection{Perancangan Sistem}

\subsubsection{Use Case Diagram}

Use Case Diagram adalah pemodelan untuk menggambarkan behavior atau kelakuan sistem yang akan dibuat. Use case diagram menggambarkan sebuah interaksi antara satu atau lebih aktor dengan sistem yang akan dibuat. Secara, sederhana, diagram use case digunakan untuk memahami fungsi apa saja yang ada di dalam sebuah sistem dan siapa saja yang dapat menggunakan fungsi-fungsi tersebut.

Menurut Rosa dan Salahudin use case diagram tidak menjelaskan secara detail tentang penggunaan tiap use case, namun hanya memberi gambaran singkat hubungan antara use case, aktor, dan sistem. Melalui use case diagram kita dapat mengetahui fungsi-fungsi apa saja yang ada pada sistem (RosaSalahudin, 2011).

Pada game ini penulis membagi sistem menjadi beberapa bagian agar sistem berjalan dengan semestinya. User memilih alur yang sesuai dengan sistem yang menjalankan dengan perintah yang sudah ditentukan. Pada gambar berikut menunjukan use case pada game menjalankan dengan perintah yang sudah ditentukan.

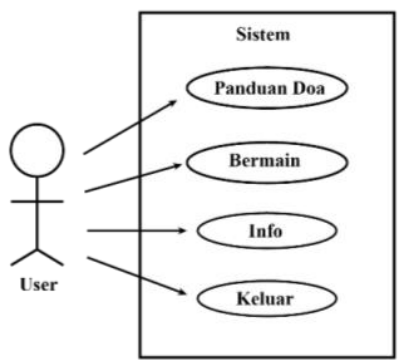

Gambar 3. 2 Use Case Diagram Sumber : penulis

Saat aktor memilih tombol panduan doa, sistem akan merespon menuju ke panduan doa-doa harian yang ada di permainan. Saat aktor memilih tombol bermain, maka sistem merespon menuju ke permainan yang dimana terdapat 3 misi yaitu mencocokan doa, menebak doa, melengkapi doa. Saat aktor memilih tombol pengaturan, sistem menampilkan layout pengaturan, yaitu pengaturan musik dan suara. Saat aktor memilih tombol info, sistem akan menampilkan info tentang aplikasi. Saat aktor memilih tombol keluar, sistem merespon untuk keluar aplikasi.

\subsubsection{Flowchart}

Flowchart merupakan suatu jenis diagram yang mempresentasikan algoritma atau Langkah-langkah instruksi yang berurutan dalam sistem. Biasanya, seorang analis sistem 
menggunakan flowchart sebagai bukti dokumentasi untuk menjelaskan gambaran logis sebuah sistem yang akan dibangun kepada programmer.

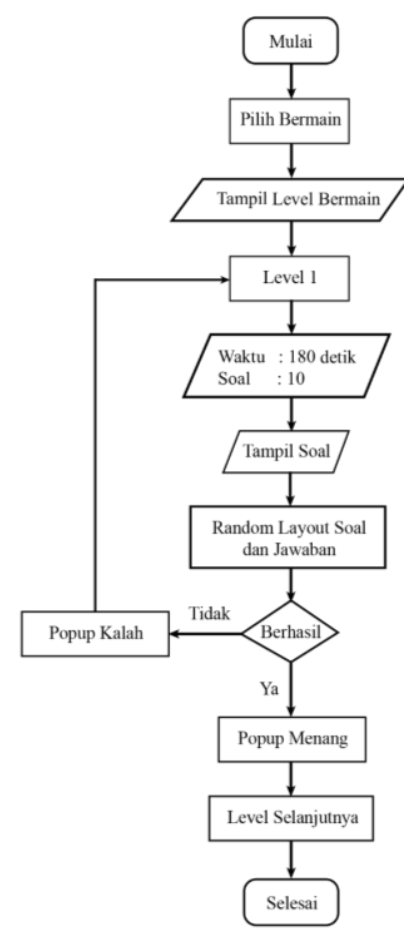

Gambar 3. 3 Flowchart Level 1 Sumber: penulis

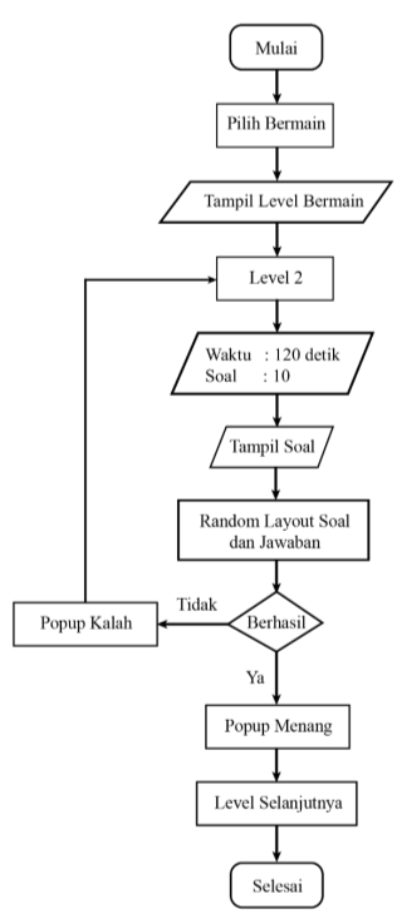

Gambar 3. 4 Flowchart Level 2 Sumber : penulis

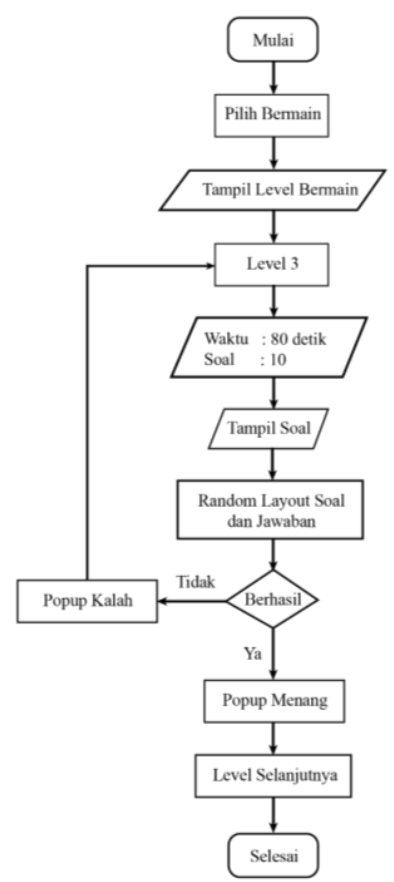

Gambar 3. 5 Flowchart Level 3 Sumber : penulis

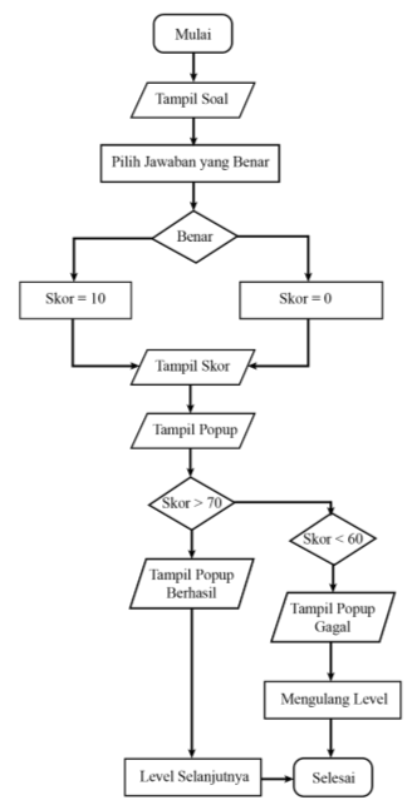

Gambar 3. 6 Flowchart Score

Sumber : penulis

\subsection{Perancangan Antarmuka (User Interface)}

\subsubsection{Struktur Menu}

Sebelum penulis membuat desain material game dengan software Adobe Ilustrator dan Photoshop. Penulis membuat struktur menu dan desain layout untuk membantu pengerjaan dan penempatan material game yang akan dibuat, selain itu struktur dan desain layout awal juga dapat menjadi panduan 
untuk mengetahui menu apa saja yang terdapat pada game sehingga hasil akhir tidak terlalu menyimpang dari konsep awal.

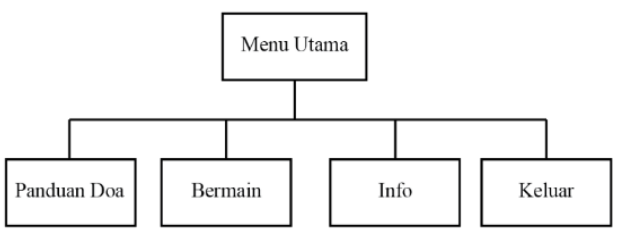

Gambar 3. 7 Struktur Menu

Sumber : penulis

\subsubsection{Rancangan Tampilan Menu Utama}

Halaman menu utama merupakan tampilan awal dari sebuah game, pada halaman utama game edukasi ini terdapat judul dari game, serta 4 button yang dapat di akses, yaitu panduan doa, bermain, info, dan keluar. Masing-masing button mempunyai fungsi. Button panduan doa akan menghubungkan menu utama ke panduan doa-doa harian, button bermain akan menghubungkan menu utama ke halaman level permainan, button info akan menghubungkan menu utama ke halaman info aplikasi dan info pembuat game, sedangkan button keluar untuk keluar dari game.

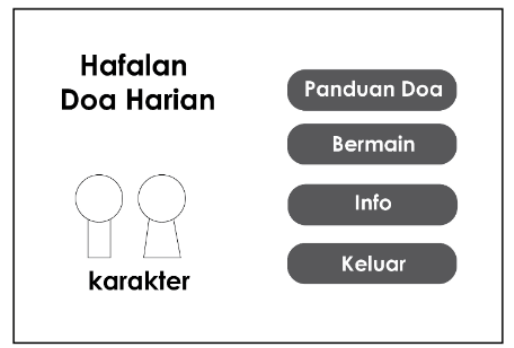

Gambar 3. 8 Rancangan Tampilan Menu Utama

Sumber : penulis

\subsubsection{Rancangan Tampilan Menu Panduan Doa}

Ketika pemain memilih menu panduan doa, maka pemain akan menuju ke halaman panduan doa. Di halaman ini pengguna dapat mengetahui macam-macam doa harian. Dihalaman ini juga terdapat 1 button yaitu button menu, yang berfungsi untuk mengakses ke halaman menu utama.

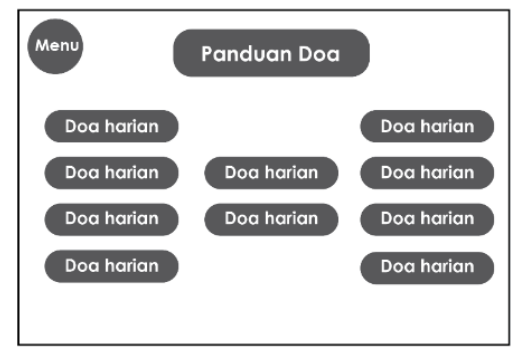

Gambar 3. 9 Rancangan Tampilan Menu Panduan Doa Sumber : penulis

\subsubsection{Rancngan Tampilan Pilih Doa Harian}

Ketika pemain memilih salah satu doa harian di menu panduan doa, maka pemain akan menuju ke halaman bacaan doa harian yang berupa tulisan arab, latin serta artinya. Dihalaman ini juga terdapat 2 button yaitu button menu dan tutup, button menu berfungsi untuk mengakses ke halaman menu utama, sedangkan button tutup berfungsi untuk mengakses ke halaman panduan doa.

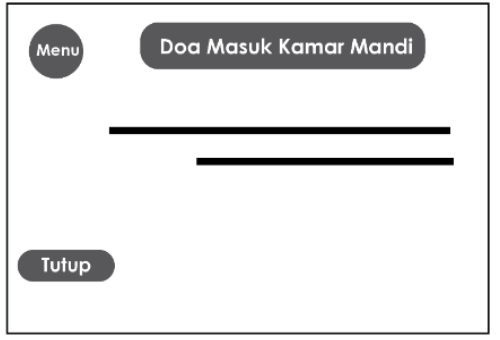

\section{Gambar 3. 10 Rancangan Tampilan Pilih Doa Harian} Sumber : penulis

\subsubsection{Rancangan Tampilan Menu Bermain}

Ketika pemain memilih menu bermain, maka pemain akan menuju kehalaman pilih level. Di halaman ini pengguna dapat memilih level yang akan dimainkan. Terdapat 3 level game, dan di antara level tersebut hanya level 1 yang sudah bisa dimainkan. Untuk ke level selanjutnya pemain harus menyelesaikan level sebelumnya terlebih dahulu. Sebelum game dimulai terdapat tombol info yang berisi menjelaskan cara bermain di level tersebut. Level 1 memiliki misi untuk mencocokan doa yang sesuai dengan soal, level 2 memiliki misi untuk menebak doa yang tertera didalam soal, level 3 memiliki misi untuk melengkapi doa yang tertera didalam soal. Di setiap level memiliki timer yang sudah di tentukan di level 1 memilki timer 160 detik, level 2 memiliki timer 120 detik, level 2 memiliki timer 90 detik. Di halaman ini terdapat button menu yang berfungsi untuk mengakses ke halaman utama.

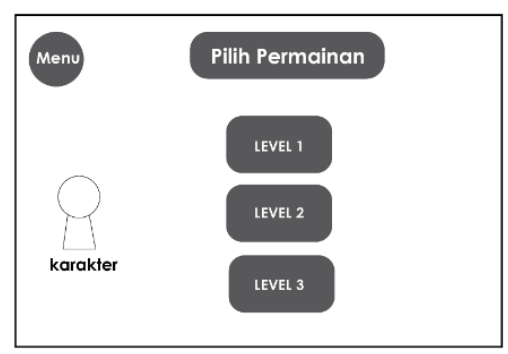

Gambar 3. 11 Rancangan Tampilan Menu Bermain Sumber : penulis 


\subsubsection{Rancangan Tampilan Pilih Mencocokan Doa}

Halaman level 1 terdapat 5 button, yaitu menu, musik, jeda, sound, dan pilihan ganda. Button menu untuk mengakses ke halaman menu utama, button musik untuk on atau off music saat permainan berlangsung, button sound untuk mendengarkan lafadz doa agar bisa mencocokan dengan soal sehingga pemain bisa menjawab soal, button pilihan ganda A, B, dan C, pilih salah satu tombol tersebut jika sudah mengetahui jawabannya, sehingga muncul soal berikutnya.

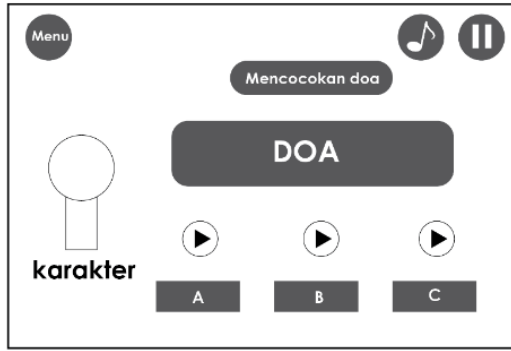

Gambar 3. 12 Rancangan Tampilan Mencocokan Doa Sumber : penulis

\subsubsection{Rancangan Tampilan Pilih Menebak Doa}

Halaman level 2 terdapat 5 button, yaitu menu, musik, jeda, sound, dan pilihan ganda. Button menu untuk mengakses ke halaman menu utama, button musik untuk on atau off music saat permainan berlangsung, button sound untuk mendengarkan lafadz doa yang terdapat di soal, button pilihan ganda A, B, dan $\mathrm{C}$, pilih salah satu tombol tersebut jika sudah mengetahui jawabannya, sehingga muncul soal berikutnya.

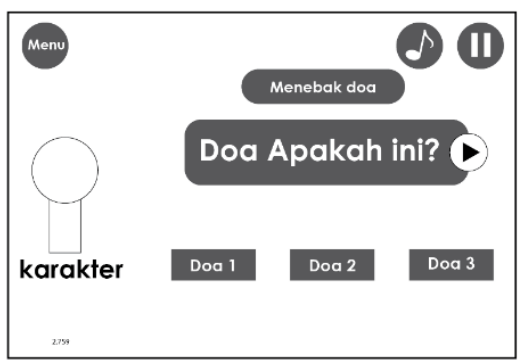

Gambar 3. 13 Rancangan Tampilan Pilih Menebak Doa Sumber : penulis

\subsubsection{Rancangan Tampilan Pilih Melengkapi Doa}

Halaman level 3 terdapat 4 button, yaitu menu, musik, jeda, sound, dan pilihan ganda. Button menu untuk mengakses ke halaman menu utama, button musik untuk on atau off music saat permainan berlangsung, button pilihan ganda A, B, C, dan D pilih salah satu tombol tersebut jika sudah mengetahui jawabannya, sehingga muncul soal berikutnya.

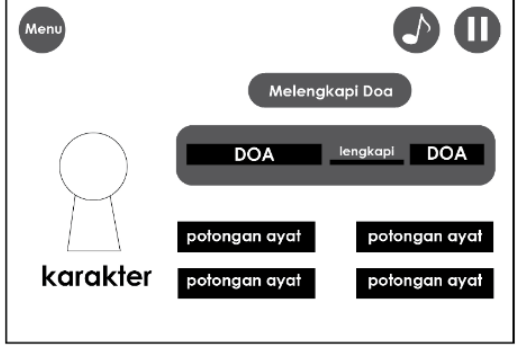

Gambar 3. 14 Rancangan Tampilan Pilih Melengkapi Doa Sumber : penulis

\subsubsection{Rancangan Tampilan Menu Info}

Pada halaman info ini terdapat informasi tambahan mengenai penjelasan tentang aplikasi "Mengahafal Doa-Doa Harian" ini dan informasi pembuat game ini.

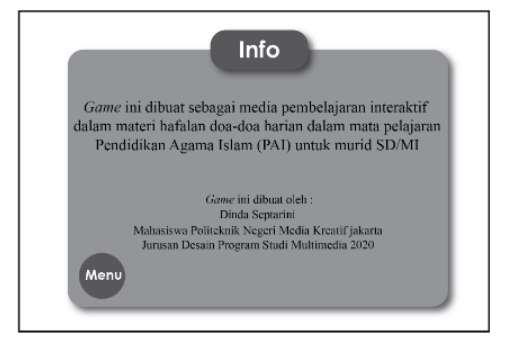

Gambar 3. 15 Rancangan Tampilan Menu Info Sumber : penulis

\subsubsection{Rancangan Tampilan Popup Jeda}

Pada halaman jeda ini terdapat 2 button, yaitu button lanjut dan button ulangi. Button lanjut berfungsi untuk melanjutkan permainan yang belum sempat di selesaikan, button ulangi, untuk mengulang soal, skor, dan timer dari soal pertama.

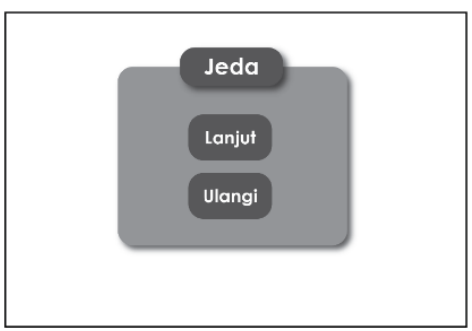

Gambar 3. 16 Rancangan Tampilan Popup Jeda Sumber : penulis

\subsubsection{Rancangan Tampilan Popup Menang}

Popup berhasil muncul ketika pemain berhasil menyelesaikan setiap level dalam permainan dan mendapatkan skor sesuai dengan berapa soal pemain menjawab pertanyaan dengan benar. Lalu pemain dapat lanjut ke level berikutnya. 


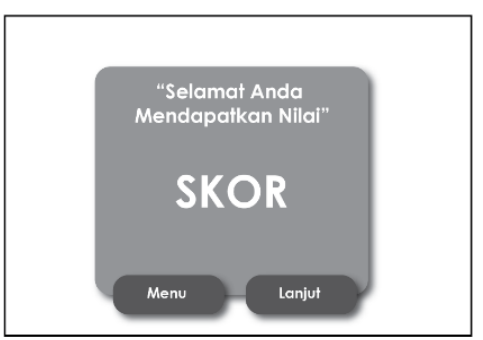

Gambar 3. 17 Rancangan Tampilan Popup Menang

Sumber : penulis

\subsubsection{Rancangan Tampilan Popup Gagal}

Popup gagal muncul ketika pemain tidak bisa mengerjakan soal sampai selesai ketika waktu sudah habis. Pemain tidak bisa lanjut ke level berikutnya jika belum menyelesaikan level sebelumnya.

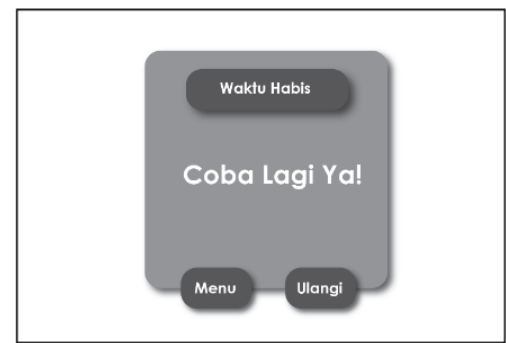

Gambar 3. 18 Rancangan Tampilan Popup Gagal Sumber : penulis

\section{HASIL DAN PEMBAHASAN}

\subsection{Implementasi Sistem}

\subsubsection{Implementasi User Interface}

Implementasi user interface menunjukkan asset dan desain user interface yang digunakan dalam aplikasi game edukasi Menghafal Doa-Doa Harian ini dibuat dan di realisasikan menggunakan Adobe Illustrator CC 2017. Ada beberapa asset yang dibuat berupa karakter, background menu, info, level, button, dan lain-lain. Dalam pembuatan asset penulis mencari referensi melalui internet, lalu diinput ke dalam Adobe Illustrator. Untuk membuat object yang dinamis penulis menggunakan tools yaitu pen tool. Untuk warna dibutuhkan fitur swatches atau fill dan gradient. Berikut implementasi user interface game.

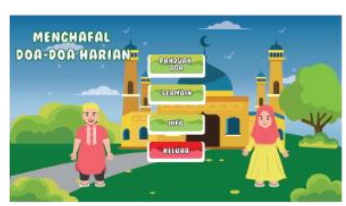

Nama : Menu Utama

Ukuran : $528 \mathrm{~KB}$

Dimendi : $720 \mathrm{px} \times 1280 \mathrm{px}$

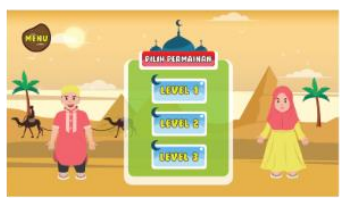

Nama : Bermain

Ukuran : $526 \mathrm{~KB}$

Dimendi : 720px X 1280px

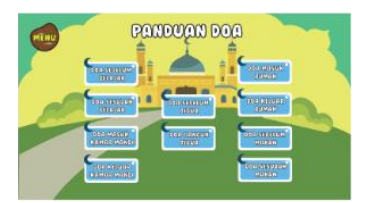

Nama : Panduan Doa

Ukuran : $508 \mathrm{~KB}$

Dimendi : 720 px X 1280px

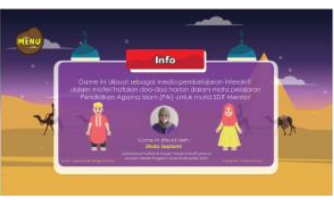

Nama : Info

Ukuran : $539 \mathrm{~KB}$

Dimendi : 720px X 1280px

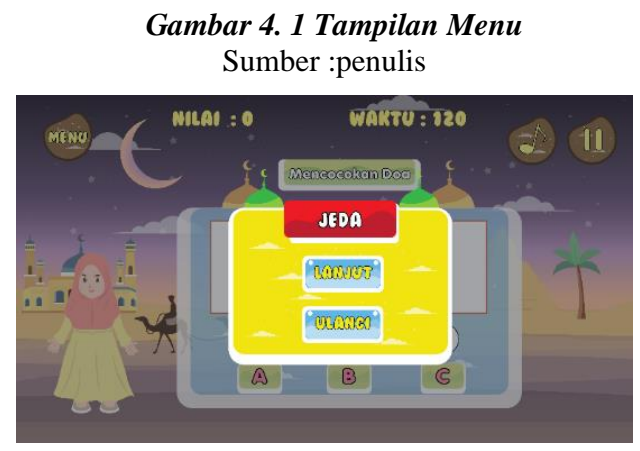

Gambar 4. 2 Tampilan Jeda Sumber : penulis

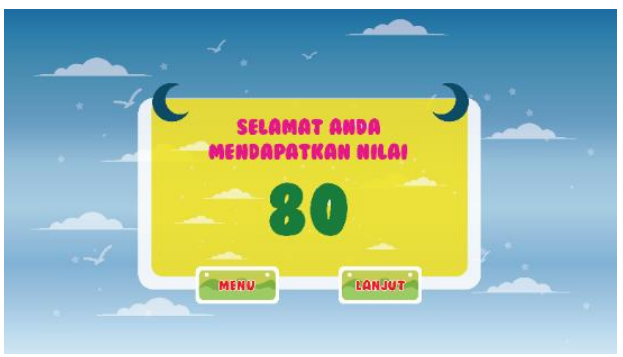

Gambar 4. 3 Tampilan Popup Berhasil Sumber : data penulis

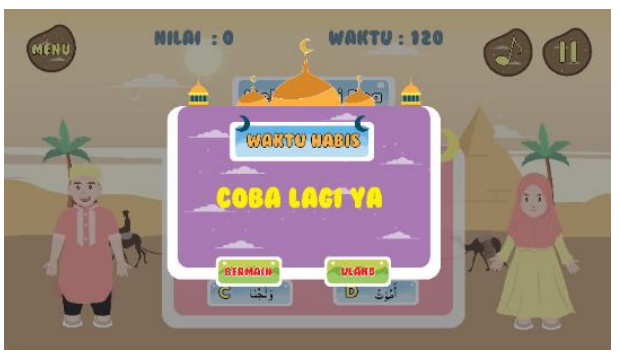

Gambar 4. 4 Tampilan Menu Gagal Sumber : penulis 


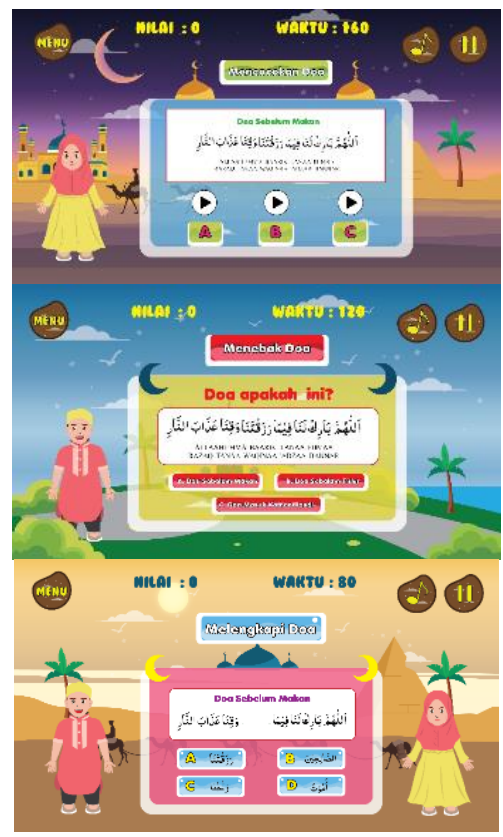

Gambar 4. 5 Tampilan Level Sumber : penulis

\subsection{Kebutuhan Pemakaian Sistem}

1. Objek Game

Objek Game yang dibutuhkan pada game, seperti background, karakter, random soal, button, logo, teks, dan objek pelengkap lainnya.

a) Aplikasi yang digunakan : Adobe Illustrator CC 2017

b) Ukuran yang di gunakan :

- Background : $1280 \times 720$ pixel

- $\quad$ Рорир

744 x 649 pixel (Popup Jeda)

995 x 892 pixel (Popup Gagal)

885 x 742 pixel (Popup Berhasil)

417 x 521 pixel (Popup jawaban benar) 417 x 521 pixel (Popup jawaban salah)

- Button

167 x 196 pixel (Button lingkaran)

165 x 204 pixel (Button persegi Panjang)

- Color Mode : CMYK (Cyan, Magenta, Yellow, Black)
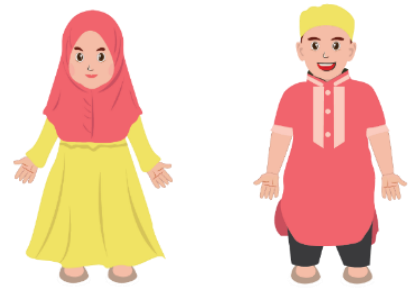

3303020
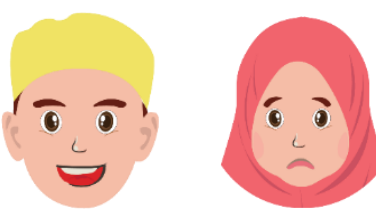

Gambar 4. 6 Objek Game

Sumber : penulis

\subsection{Pengujian Sistem}

Tabel 4. 1 Spesifikasi Perangkat Android

\begin{tabular}{|c|c|c|c|c|}
\hline \multirow{2}{*}{$\begin{array}{l}\text { Perangkat } \\
\text { Smartphon } \\
\text { e Android }\end{array}$} & \multicolumn{4}{|c|}{ Spesifikasi Peringkat } \\
\hline & Processor & $\begin{array}{c}\text { RA } \\
\text { M }\end{array}$ & $\begin{array}{l}\text { Ukura } \\
\text { n } \\
\text { Layar }\end{array}$ & $\begin{array}{c}\text { OS } \\
\text { Androi } \\
d\end{array}$ \\
\hline $\begin{array}{l}\text { Perangkat } \\
1\end{array}$ & $\begin{array}{l}\text { Octa-core } \\
\text { Exynos } \\
8890\end{array}$ & $\begin{array}{c}4 \\
G B\end{array}$ & 5 inch & $\begin{array}{c}\text { Androi } \\
\text { d } 8.0 \\
\text { Oreo }\end{array}$ \\
\hline $\begin{array}{l}\text { Perangkat } \\
2\end{array}$ & $\begin{array}{l}\text { Qualcom } \\
\text { m } \\
\text { Snapdrago } \\
\text { n } 660\end{array}$ & $\begin{array}{c}4 \\
\text { GB }\end{array}$ & $\begin{array}{l}6.26 \\
\text { inch }\end{array}$ & $\begin{array}{c}\text { Androi } \\
\text { d } 8.1 \\
\text { Oreo }\end{array}$ \\
\hline $\begin{array}{l}\text { Perangkat } \\
3\end{array}$ & Octa Core & $\begin{array}{c}3 \\
\text { GB }\end{array}$ & $\begin{array}{l}5.2 \\
\text { inch }\end{array}$ & $\begin{array}{c}\text { Lollipo } \\
\text { p }\end{array}$ \\
\hline $\begin{array}{l}\text { Perangkat } \\
4\end{array}$ & Octa Core & $\begin{array}{c}3 \\
\mathrm{~GB}\end{array}$ & 5 inch & Nougat \\
\hline
\end{tabular}

(Sumber : penulis)

Setelah seluruh perangkat sudah disiapkan, kemudian dilakukan instalasi aplikasi pada masing-masing perangkat. Setelah itu maka akan dilakukan pengujian berdasarkan indicator. Berikut adalah hasil uji coba aplikasi di empat perangkat android :

Tabel 4. 2 Hasil Uji Perangkat

\begin{tabular}{|l|c|c|c|c|}
\hline \multirow{2}{*}{$\begin{array}{l}\text { Proses } \\
\text { Operasi }\end{array}$} & \multicolumn{4}{|c|}{ Perangkat Smartphone Android } \\
\cline { 2 - 5 } & $\begin{array}{c}\text { Perang- } \\
\text { kat 1 }\end{array}$ & $\begin{array}{c}\text { Perang- } \\
\text { kat 2 }\end{array}$ & $\begin{array}{c}\text { Perang- } \\
\text { kat 3 }\end{array}$ & $\begin{array}{c}\text { Perang- } \\
\text { kat 4 }\end{array}$ \\
\hline Instalasi & $\begin{array}{l}\text { Berjalan } \\
\text { dengan } \\
\text { baik }\end{array}$ & $\begin{array}{l}\text { Berjalan } \\
\text { dengan } \\
\text { baik }\end{array}$ & $\begin{array}{l}\text { Berjalan } \\
\text { dengan } \\
\text { baik }\end{array}$ & $\begin{array}{l}\text { Berjalan } \\
\text { dengan } \\
\text { baik }\end{array}$ \\
\hline $\begin{array}{l}\text { Durasi } \\
\text { sampai ke } \\
\text { menu utama }\end{array}$ & 8 detik & 9 detik & 10 detik & 10 detik \\
\hline $\begin{array}{l}\text { Durasi dari } \\
\text { main menu } \\
\text { ke menu } \\
\text { level 1 }\end{array}$ & 4 detik & 4 detik & 8 detik & 5 detik \\
\hline
\end{tabular}




\begin{tabular}{|l|l|l|l|l|}
\hline $\begin{array}{l}\text { Menu } \\
\text { Panduan }\end{array}$ & $\begin{array}{l}\text { Berjalan } \\
\text { dengan } \\
\text { baik }\end{array}$ & $\begin{array}{l}\text { Berjalan } \\
\text { dengan } \\
\text { baik }\end{array}$ & $\begin{array}{l}\text { Berjalan } \\
\text { dengan } \\
\text { baik }\end{array}$ & $\begin{array}{l}\text { Berjalan } \\
\text { dengan } \\
\text { baik }\end{array}$ \\
\hline Luas layar & Baik & $\begin{array}{l}\text { Minus } \\
\text { bagian } \\
\text { hitam 1 } \\
\text { cm sisi } \\
\text { kiri dan } \\
\text { sisi } \\
\text { kanan }\end{array}$ & Baik & Baik \\
\hline $\begin{array}{l}\text { Fungsi } \\
\text { Audio }\end{array}$ & Baik & Baik & Baik & Baik \\
\hline $\begin{array}{l}\text { Kejernihan } \\
\text { Gambar }\end{array}$ & Baik & Baik & Baik & Baik \\
\hline $\begin{array}{l}\text { Kelengkapan } \\
\text { Tampilan }\end{array}$ & Baik & Baik & Baik & Baik \\
\hline
\end{tabular}

(Sumber : penulis)

Berdasarkan hasil pengujian sesuai table yang diatas, terlihat dapat disimpukan bahwa game ini dapat di instalisasi di semua perangkat. Adapun perbedaan-perbedaan yang terjadi pada kecepatan proses game, dikarenakan perbedaan unit prosesor dan RAM pada tiap perangkat. Perbedaan layar hitam pada tampilan juga disebabkan karena perbedaan ukuran layar pada tiap perangkat. Selainnya pada manu panduan doa, fungsi audio, kejernihan gambar dan kelengkapan tampilan berjalan dengan baik.

Tabel 4. 3 Spesifikasi Perangkat Android

\begin{tabular}{|l|l|c|c|c|}
\hline \multirow{2}{*}{$\begin{array}{l}\text { Perangkatphon } \\
\text { e Android }\end{array}$} & \multicolumn{4}{|c|}{ Spesifikasi Peringkat } \\
\cline { 2 - 5 } & & $\begin{array}{c}\text { RA } \\
\mathrm{M}\end{array}$ & $\begin{array}{c}\text { Ukura } \\
\mathrm{n} \\
\text { Layar }\end{array}$ & OS Android \\
\hline $\begin{array}{l}\text { Perangkat } \\
1\end{array}$ & $\begin{array}{l}\text { Qualcomm }{ }^{8} \\
\text { Snapdragon } \\
\text { TM 625 }\end{array}$ & $4 \mathrm{~GB}$ & $\begin{array}{c}5,84 \\
\text { inch }\end{array}$ & $\begin{array}{c}\text { Android 8.1 } \\
\text { (Oreo) }\end{array}$ \\
\hline $\begin{array}{l}\text { Perangkat } \\
2\end{array}$ & Octa Core & $6 \mathrm{~GB}$ & $\begin{array}{c}6.5 \\
\text { inch }\end{array}$ & $\begin{array}{c}\text { Android 9.0 } \\
\text { (pie) }\end{array}$ \\
\hline $\begin{array}{l}\text { Perangkat } \\
3\end{array}$ & $\begin{array}{l}\text { Quad-core } \\
1.2 \quad \text { GHz }\end{array}$ & $2 \mathrm{~GB}$ & 5 inch & $\begin{array}{c}\text { Marshmallo } \\
\text { W }\end{array}$ \\
\hline $\begin{array}{l}\text { Perangkat } \\
4\end{array}$ & Octa Core & $4 \mathrm{~GB}$ & $\begin{array}{c}5.7 \\
\text { inch }\end{array}$ & $\begin{array}{c}\text { Android 8.0 } \\
\text { (Oreo) }\end{array}$ \\
\hline
\end{tabular}

\section{(Sumber : user)}

Setelah seluruh perangkat sudah disiapkan, kemudian dilakukan instalasi aplikasi pada masing-masing perangkat. Setelah itu maka akan dilakukan pengujian berdasarkan indicator. Berikut adalah hasil uji coba aplikasi di empat perangkat android:

Tabel 4. 4 Hasil Uji Perangkat

\begin{tabular}{|l|l|l|l|l|}
\hline \multirow{2}{*}{ Proses } & \multicolumn{4}{|c|}{ Perangkat Smartphone Android } \\
\cline { 2 - 5 } & Perangka & Perangka & Perangka & Perangka \\
\hline
\end{tabular}

\begin{tabular}{|c|c|c|c|c|}
\hline $\begin{array}{l}\text { Operasi } \\
\text { Aplikasi }\end{array}$ & t 1 & t 2 & t 3 & $\mathrm{t} 4$ \\
\hline Instalasi & $\begin{array}{l}\text { Berjalan } \\
\text { dengan } \\
\text { baik }\end{array}$ & $\begin{array}{l}\text { Berjalan } \\
\text { dengan } \\
\text { baik }\end{array}$ & $\begin{array}{l}\text { Berjalan } \\
\text { dengan } \\
\text { baik }\end{array}$ & $\begin{array}{l}\text { Berjalan } \\
\text { dengan } \\
\text { baik }\end{array}$ \\
\hline $\begin{array}{l}\text { Durasi } \\
\text { sampai ke } \\
\text { menu utama }\end{array}$ & 10 detik & 7 detik & 9 detik & 11 detik \\
\hline $\begin{array}{l}\text { Durasi dari } \\
\text { main menu } \\
\text { ke menu } \\
\text { level } 1\end{array}$ & 6 detik & 4 detik & 4 detik & 8 detik \\
\hline $\begin{array}{l}\text { Menu } \\
\text { Panduan } \\
\text { Doa }\end{array}$ & $\begin{array}{l}\text { Berjalan } \\
\text { dengan } \\
\text { baik }\end{array}$ & $\begin{array}{l}\text { Berjalan } \\
\text { dengan } \\
\text { baik } \\
\end{array}$ & $\begin{array}{l}\text { Berjalan } \\
\text { dengan } \\
\text { baik }\end{array}$ & $\begin{array}{l}\text { Berjalan } \\
\text { dengan } \\
\text { baik }\end{array}$ \\
\hline Luas layar & Baik & \begin{tabular}{lr}
\multicolumn{2}{l}{ Minus } \\
bagian \\
hitam 1 \\
$\mathrm{~cm} \quad$ sisi \\
kiri dan \\
sisi \\
kanan
\end{tabular} & Baik & Baik \\
\hline $\begin{array}{l}\text { Fungsi } \\
\text { Audio }\end{array}$ & Baik & Baik & Baik & Baik \\
\hline $\begin{array}{l}\text { Kejernihan } \\
\text { Gambar }\end{array}$ & Baik & Baik & Baik & Baik \\
\hline $\begin{array}{l}\text { Kelengkapa } \\
\text { n Tampilan }\end{array}$ & Baik & Baik & Baik & Baik \\
\hline
\end{tabular}

(Sumber : user)

Berdasarkan hasil pengujian sesuai tabel yang diatas, terlihat dapat disimpukan bahwa game ini dapat di instalisasi di semua perangkat. Adapun perbedaan-perbedaan yang terjadi pada kecepatan proses game, dikarenakan perbedaan unit prosesor dan RAM pada tiap perangkat. Perbedaan layar hitam pada tampilan juga disebabkan karena perbedaan ukuran layar pada tiap perangkat. Selainnya pada manu panduan doa, fungsi audio, kejernihan gambar dan kelengkapan tampilan berjalan dengan baik.

\section{KESIMPULAN DAN SARAN}

\section{1 Simpulan}

Pada pembuatan dan perancangan game edukasi Menghafal Doa-Doa Harian melalui tahap pra produksi, produksi, hingga pasca produksi. Dimulai dari mengumpulkan data, mengidentifikasi masalah, merancang konsep, membuat sketsa, 
mendesain asset, programming, hingga eksport ke APK kemudian dilanjutkan dengan testing aplikasi dan publishing. Pembuatan game ini menggunakan software Adobe Illustrator dan Unity $3 D$, sedangkan hardware menggunakan laptop dan handphone. Berdasarkan uji coba developer, aplikasi ini memiliki performance terbaik pada perangkat dengan processor Octa-core Exynos 8890 serta RAM 4 Gb. Sedangkan berdasarkan uji coba user, aplikasi ini memiliki performance terbaik pada perangkat 2 dengan processor Octa Core serta RAM 6 Gb. Kemudian berdasarkan hasil kuesioner para siswa menyatakan bahwa aplikasi ini mudah digunakan, aplikasi berjalan dengan baik, game tersebut tampilannya terlihat menarik yang dapat membantu meningkatkan minat siswa dalam menghafal, informasi yang disajikan mudah dimengerti, bahasa dalam game mudah dipahami, siswa tertarik untuk menggunakan game edukasi ini, serta aplikasi game ini sangat berpengaruh bagi siswa dalam menghafal doa-doa harian, yang mulanya siswa menghafal selama 6 jam perhari, setelah menggunakan aplikasi ini siswa menghafal selama 3 jam sampai 4 jam perhari Berikut merupakan kesimpulan dan karya penulis.

\section{2 Saran}

Adapun saran-saran dari penulis kepada pembaca yang mungkin akan membuat karya serupa dengan penulis adalah :

a. Saran dari user, karakter yang ada di aplikasi game dibuat menjadi gerak

b. Dapat dipublikasikan kepada masyarakat umum, seperti di Play Store dan App Store.

\section{DAFTAR PUSTAKA}

[1] _Mursalim,"Doa Dalam Perspektif Al-Qur'an,” Jurnal AlUlum, vol. 11, pp. 63-78, 2011.

[2] M.Saifudin. "Doa adalah Ibadah". Internet: https://muslim.or.id/29861-doa-adalah-ibadah-01.html, April. 29, 2017 [Juni. 17, 2020].

[3] Muzliah Rizka Hamadi, Arie S. M. Lumenta, Muhamad D. Putro. "Rancang Bangun Aplikasi Game Edukasi Hafalan Doa Agama Islam". E-Jurnal Teknik Informatika, vol. 12, ISSN: 2301-8364, 2017.

[4] Anonim.

"Game". Internet: http://eprints.umpo.ac.id/3045/3/BAB\%20II.pdf, [Juni. 20, 2020]

[5] Sinta. "Game Edukasi". Internet: //sinta.unud.ac.id/uploads/wisuda/0904505070-3 BAB\%20II.pdf, [Juni. 20, 2020]
[6] Afrida Nur. "Android". Internet: http://repository.ump.ac.id/2748/3/BAB\%20II_AFRIDA\% 20NUR\%20FAUZY_TI\%2714.pdf, 2017 [Juni.21,2020].

[7] Anonim. "Pengertian Android". Internet: //eprints.polsri.ac.id/5596/3/BAB\%20II.pdf, [Juni.21.2020]

[8] Anonim. "Pengertian Android". Internet: //digilib.unila.ac.id/14588/2/BAB\%20II.pdf, [Juni.21,2020]

[9] Om.makpulus. "Pentingnya Do'a Harian Bagi Anak Usia Dini". Internet: http://www.definisipengertian.com/2015/06/pentingnya-doa-harian-bagi-anakusia.html, 2015 [Juni.22,2020]

[10] Syafitri, Irmayani. "Pengertian Flowchart Beserta Fungsi dan Simbol-simbol Flowchart yang Paling Umum Digunakan". Internet: https://www.nesabamedia.com/pengertian-flowchart/, Juli.10,2019 [Juni.22,2020]

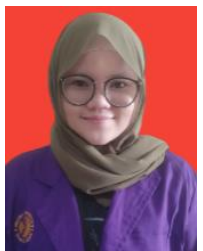

\section{BIODATA PENULIS}

\section{Dinda Septarini}

Dinda Septarini lahir di Bogor pada tanggal 22 September 1998, merupakan mahasiswa tingkat akhir Jurusann Desain Grafis Konsentrasi Multimedia, Politeknik Negeri Media Kreatif Jakarta. Selama masa perkuliahan telah perperan aktif mengikuti organisasi dan kegiatan seminar, yaitu menjabat sebagai Bendahara Himpunan di tahun 2018/2020, mengikuti seminar WIMNUS sebagai peserta Motivasi Nasional Entrepreneur Series di tahun 2018, mengikuti seminar WIMNUS Public Speaking Series, mengikuti kegiatan kepanitiaan acara kampus sebagai Divisi Dokumentasi. 